\title{
The Transfer of Iron to Reticulocytes by Synthetic Chelating Agents *
}

\author{
Joseph V. Princiotto, Martin Rubin, George C. Shashaty, and \\ EDWARD J. ZAPOLSKI \\ (From the Departments of Physiology and of Biophysics and Biochemistry, Georgetown \\ University Schools of Medicine and Dentistry, Washington, D. C.)
}

Iron, once absorbed from the gastrointestinal tract, is distributed throughout the body by the specific iron-binding protein (IBP, transferrin, siderophilin) (1). Iron binding by IBP is presumed to be of a chelate type in which the hexacoordination capacity of the ferric ion is satisfied by linkage with three phenolic oxygens, one carboxyl group, and a bicarbonate ion on the remaining coordination position (2-4). Since IBP has been shown to have a highly selective ability to deliver iron to the immature red cell (5), we have utilized various synthetic iron chelates in an attempt to delineate the characteristics for iron binding essential to carry out this function of the protein.

\section{Methods}

Preparation of the reticulocyte-rich blood. Reticulocytosis was produced in adult albino rabbits ( 3 to $5 \mathrm{~kg}$ ) by removing approximately 5 to $10 \%$ of the total blood volume ( 30 to $40 \mathrm{ml})$ daily for 3 or 4 days by repeated cardiac puncture. Two days thereafter, a final cardiac puncture delivered all available blood, which was immediately placed into iron-free, heparinized glass containers. Reticulocyte count using the new methylene blue stain technique (6) indicated 10 to $25 \%$ immature cells.

The red cells were separated from the plasma and leukocytes by centrifugation at $1,000 \times g$ for $15 \mathrm{~min}-$ utes at $4^{\circ} \mathrm{C}$. The harvested cells were washed and centrifuged three times with 5 vol of iron-free, phosphate

* Submitted for publication July 29, 1963; accepted December 26, 1963.

This investigation was supported in part by $U$. S. Public Health Service research grant A 4447 (to Dr. Princiotto) and in part by American Medical Association Education and Research Foundation grants A 473 and AMRF 40.

A preliminary report of these results was presented to the 45th Annual Meeting of the Federation of American Societies for Experimental Biology, Atlantic City, N. J., April 12, 1961. buffered ( $\mathrm{pH}$ 7.4) Ringer's solution and then made up to a $50 \%$ suspension by dilution with the buffer.

Control red cells low in reticulocytes were prepared from previously unbled animals.

Preparation of the incubating media. Iron-binding protein $^{1}$ was made up in $30 \mu \mathrm{M}$ solution in Ringer's solution. Ferric chloride solution, $1.0 \mathrm{mM}$, tracer amounts of $\mathrm{Fe}^{50} \mathrm{Cl}_{3}$, and Ringer's solution were added to yield approximately $100,000 \mathrm{cpm}$ per $5 \mathrm{ml}$ in a well-type scintillation counter ${ }^{2}$ at a final iron concentration of $15 \mu \mathrm{M}$ and IBP concentration of $15 \mu \mathrm{M}$. Sodium bicarbonate $\left(10^{-2} \mathrm{M}\right)$ was added to insure complete iron binding by IBP, and the $\mathrm{pH}$ was adjusted to 7.4 with phosphate buffer. The IBP was $50 \%$ saturated when prepared as described.

The various iron chelate solutions (Figure 1, Table I, and Figure 2, Table II) were prepared by metathesis from ferric chloride and the free ligand ${ }^{3}$ in buffered Ringer's solution, with final iron concentrations of 15 $\mu \mathrm{M}$ and ligand concentrations of 30,75 , and $150 \mu \mathrm{M}$, which therefore resulted in $2: 1,5: 1$, and $10: 1$ ligand: iron molar ratios. $\mathrm{Fe}^{{ }^{50}} \mathrm{Cl}_{3}$ was added as described above. All the solutions were prepared immediately before use.

Evidence that the iron was in the chelate form was provided by hydrolytic and spectrophotometric properties. Freshly prepared solutions of ferric chloride at the same concentration, $15 \mu \mathrm{M}$, were water clear. After standing overnight they became turbid and deposited a flocculent precipitate of basic ferric hydroxides. The chelate solutions were stable to hydrolysis. Most of these compounds were intensely colored, and those compounds in Table II with the exception of $\mathrm{U}, \mathrm{V}$, and $\mathrm{W}$ were colored even after final dilution to $15 \mu \mathrm{M}$ iron concentrations. Resistance to hydrolysis and typical color development are prime characteristics of chelate compounds (7).

Procedure for study of iron transfer to cells. Two $\mathrm{ml}$ of the $50 \%$ cell suspension was incubated for 2 hours

1 Generously supplied by Dr. McClean, Cutter Laboratories, Berkeley, Calif. The $\beta_{1}$ metal combining globulin (Fraction IV-7) was obtained from normal human plasma by conventional cold ethanol fractionation and assayed $85 \% \beta$-globulin by electrophoresis.

2 Baird-Atomic, Cambridge, Mass.

${ }^{3}$ Generously supplied by Dr. M. Weiner, Geigy Chemical Corp., Ardsley, N. Y. 
A<smiles>O=C(O)CN(CC(=O)O)CC(=O)O</smiles>

ETHYLENEDIAMINETETRAACETIC ACID,IEDTA)

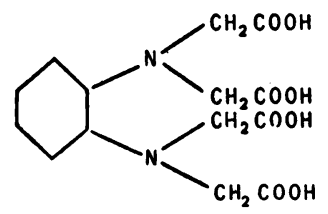

B 1,2- DIAMINOCYCLOHEXANE-N, $N^{\prime}$ TETRAACETIC ACIO (CDTA)

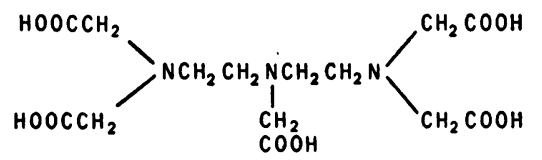

C DIETHYLENETRIAMINEPENTAACETIC ACID (DTPA)

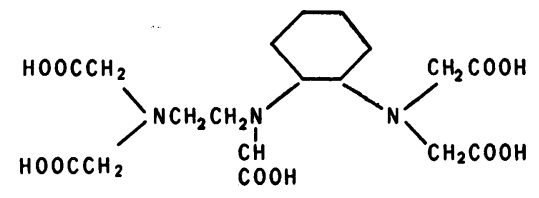

D A AMINOETHYLCYCLOHEXANE-N, N'DIAMINEPENTAACETIC ACID

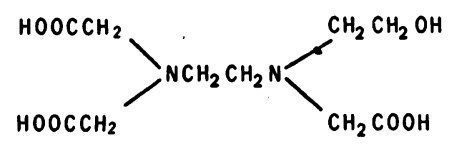

E N-B HYDROXYETHYLETHYLENEDIAMINETRIACETIC

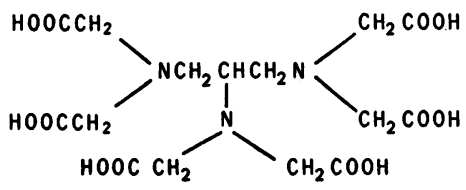

F 1,2,3-TRIAMINOPROPANE-N, $N^{\prime}, N^{\prime \prime}-$

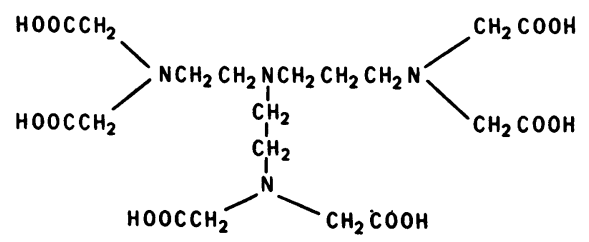

G

B. $\beta^{\prime}, \beta^{\prime \prime}$ TRIAMINOTRIETHYLAMINEHEXAACETIC ACID ("TREN" HEXAACETIC ACID)

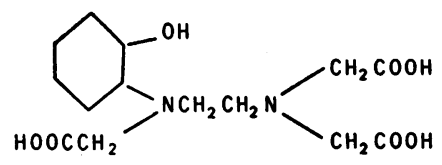

ETHYLENEDIAMINE-2-HYDROXYCYCLOHEXYLTRIACETIC ACID

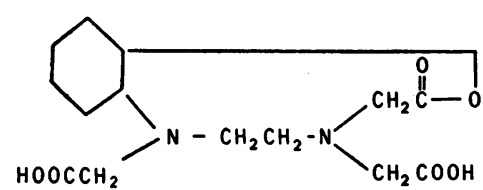

I

ETHYLENED.IAMINE -2- HYDROXYLCYCLOHEXYL TRIACETIC ACID LACTONE

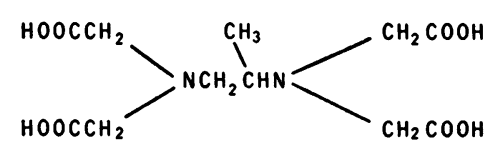

J 1.2- PROPYLENEDIAMINETETRAACETIC ACID

Fig. 1. Structures of ligands of Table I. The letters preceding the chemical names refer to the compounds listed in Table $\mathrm{I}$. 
at $37^{\circ} \mathrm{C}$ with $5 \mathrm{ml}$ of each of the prepared solutions in iron-free Lusteroid counting tubes. The mixtures were agitated frequently. The amount of iron $(4.2 \mu \mathrm{g}$ per 5 $\mathrm{ml}$ ) with which the cells were incubated was constant in these experiments. A count was made to determine the total activity in each sample. The tubes were then centrifuged at $4^{\circ} \mathrm{C}$ at $2,500 \mathrm{rpm}$ for 10 minutes, the supernatant liquid was removed, and the cells were washed three times with 5-ml vol of cold Ringer's solution and recentrifuged. Further washings caused no increase in the radioactivity of the supernatant fluid over the background count. The cells were then hemolyzed at $4^{\circ} \mathrm{C}$ for 10 to 15 minutes with $6 \mathrm{ml}$ of distilled water. The $\mathrm{pH}$ of the hemolysate was 7.5. A second determination of the radioactivity now measured the total uptake of iron by the cells. The hemolysate and stroma were separated by centrifugation at $4^{\circ} \mathrm{C}$ at $2,500 \mathrm{rpm}$ for $20 \mathrm{~min}$ utes. The stroma was then washed and centrifuged three times with cold distilled water, resuspended in $6 \mathrm{ml}$ of water, and the radioactivity measured to ca!- culate the uptake by the cell stroma. The difference between the total uptake and the stromal uptake provided the value for the hemolysate iron content. The iron concentration was calculated as micrograms of iron per milliliter of reticulocytes. The data presented are the results of at least two experiments each in duplicate for the runs in which there was no transfer of iron to reticulocytes. Other experiments, in duplicate, were repiicated between three and fifteen times with a variability within $25 \%$ of the average values reported. Reproducibility of iron transfer from chelated iron to reticulocytes was superior to that from iron transferrin.

Qualitative identification of radioiron incorporation into hemoglobin. To measure $\mathrm{Fe}^{59}$ incorporation into hemoglobin in the incubated cells, the hemoglobin was isolated by fractional phosphate precipitation according to Kruh and Borsook (8). Alternatively, hemoglobin was separated by paper electrophoresis at $\mathrm{pH} 8.6$ (barbital buffer) in a Spinco-Durrum apparatus. One strip was stained with bromphenol blue to locate hemoglobin,

TABLE I

Chelate iron uptake*

\begin{tabular}{|c|c|c|c|c|c|}
\hline Chelate & $\log K_{M A}$ & $\begin{array}{l}\text { Ligand:iron } \\
\text { ratios }\end{array}$ & $\begin{array}{r}\text { Total } \\
\text { uptake }\end{array}$ & Hemolysate & Stroma \\
\hline $\begin{array}{l}\text { A. Ethylenediaminetetraace- } \\
\text { tic acid } \\
\text { (EDTA) }\end{array}$ & 25.1 & $\begin{array}{r}2: 1 \\
5: 1 \\
10: 1\end{array}$ & $\begin{array}{l}0.1 \\
0.0 \\
0.0\end{array}$ & $\begin{array}{l}0.1 \\
0.0 \\
0.0\end{array}$ & $\begin{array}{l}0.0 \\
0.0 \\
0.0\end{array}$ \\
\hline $\begin{array}{l}\text { B. 1,2-Diaminocyclohexane- } \\
\text { N,N'-tetraacetic acid } \\
\text { (CDTA) }\end{array}$ & & $\begin{array}{r}2: 1 \\
5: 1 \\
10: 1\end{array}$ & $\begin{array}{l}0.1 \\
0.0 \\
0.0\end{array}$ & $\begin{array}{l}0.05 \\
0.0 \\
0.0\end{array}$ & $\begin{array}{l}0.05 \\
0.0 \\
0.0\end{array}$ \\
\hline $\begin{array}{l}\text { C. Diethylenetriaminepenta- } \\
\text { acetic acid } \\
\text { (DTPA) }\end{array}$ & 28.6 & $\begin{array}{r}2: 1 \\
5: 1 \\
10: 1\end{array}$ & $\begin{array}{l}0.9 \\
0.2 \\
0.2\end{array}$ & $\begin{array}{l}0.3 \\
0.05 \\
0.05\end{array}$ & $\begin{array}{l}0.6 \\
0.15 \\
0.15\end{array}$ \\
\hline $\begin{array}{l}\text { D. } \beta \text {-Aminoethylcyclohexane- } \\
\text { N,N'-diaminepenta- } \\
\text { acetic acid }\end{array}$ & & $\begin{array}{r}2: 1 \\
5: 1 \\
10: 1\end{array}$ & $\begin{array}{l}0.1 \\
0.1 \\
0.0\end{array}$ & $\begin{array}{l}0.05 \\
0.05 \\
0.0\end{array}$ & $\begin{array}{l}0.05 \\
0.05 \\
0.0\end{array}$ \\
\hline $\begin{array}{l}\text { E. N- } \beta \text { Hydroxyethylethylene- } \\
\text { diaminetriacetic acid } \\
\text { (HEDTA) }\end{array}$ & 19.6 & $\begin{array}{r}2: 1 \\
5: 1 \\
10: 1\end{array}$ & $\begin{array}{l}0.8 \\
0.1 \\
0.0\end{array}$ & $\begin{array}{l}0.3 \\
0.05 \\
0.0\end{array}$ & $\begin{array}{l}0.5 \\
0.05 \\
0.0\end{array}$ \\
\hline $\begin{array}{l}\text { F. 1,2,3-Triaminopropane- } \\
\text { N,N } N^{\prime}, N^{\prime \prime} \text {-hexaacetic } \\
\text { acid }\end{array}$ & & $\begin{array}{r}2: 1 \\
5: 1 \\
10: 1\end{array}$ & $\begin{array}{l}0.8 \\
0.2 \\
0.1\end{array}$ & $\begin{array}{l}0.5 \\
0.1 \\
0.05\end{array}$ & $\begin{array}{l}0.3 \\
0.1 \\
0.05\end{array}$ \\
\hline $\begin{array}{c}\text { G. } \beta, \beta^{\prime}, \beta^{\prime \prime} \text { Triaminotriethyl- } \\
\text { aminehexaacetic acid }\end{array}$ & & $\begin{array}{r}2: 1 \\
5: 1 \\
10: 1\end{array}$ & $\begin{array}{l}0.1 \\
0.1 \\
0.0\end{array}$ & $\begin{array}{l}0.0 \\
0.0 \\
0.0\end{array}$ & $\begin{array}{l}0.1 \\
0.1 \\
0.0\end{array}$ \\
\hline $\begin{array}{l}\text { H. Ethylenediamine-2-cyclo- } \\
\text { hexanol triacetic acid }\end{array}$ & & $\begin{array}{r}2: 1 \\
5: 1 \\
10: 1\end{array}$ & $\begin{array}{l}0.1 \\
0.0 \\
0.0\end{array}$ & $\begin{array}{l}0.0 \\
0.0 \\
0.0\end{array}$ & $\begin{array}{l}0.1 \\
0.0 \\
0.0\end{array}$ \\
\hline $\begin{array}{l}\text { I. Ethylenediamine-2-cyclo- } \\
\text { hexanol triacetic acid } \\
\text { lactone }\end{array}$ & & $\begin{array}{r}2: 1 \\
5: 1 \\
10: 1\end{array}$ & $\begin{array}{r}15.8 \\
3.8 \\
0.4\end{array}$ & $\begin{array}{l}1.4 \\
0.4 \\
0.1\end{array}$ & $\begin{array}{r}14.4 \\
3.4 \\
0.3\end{array}$ \\
\hline $\begin{array}{c}\text { J. 1,2-Propylenediamine- } \\
\text { N,N'-tetraacetic acid }\end{array}$ & & $\begin{array}{r}2: 1 \\
5: 1 \\
10: 1\end{array}$ & $\begin{array}{l}5.2 \\
0.4 \\
0.1\end{array}$ & $\begin{array}{l}0.8 \\
0.1 \\
0.05\end{array}$ & $\begin{array}{l}4.4 \\
0.3 \\
0.05\end{array}$ \\
\hline $\begin{array}{l}\text { K. 1,2-Bis-[(2-dicarboxy- } \\
\text { methyl) aminoethoxy }] \\
\text { ethane }\end{array}$ & & $\begin{array}{r}2: 1 \\
5: 1 \\
10: 1\end{array}$ & $\begin{array}{r}14.1 \\
11.3 \\
3.4\end{array}$ & $\begin{array}{l}3.2 \\
1.5 \\
1.0\end{array}$ & $\begin{array}{r}10.9 \\
9.8 \\
2.4\end{array}$ \\
\hline
\end{tabular}

* Calculated as micrograms of iron per milliliter of rabbit reticulocytes. 


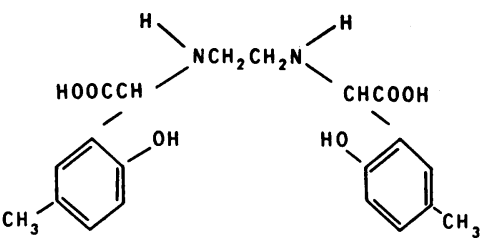

$\mathbf{L}$

$$
\text { N, N' ETHYLENEBIS La IMINO-2-HYDROXY- }
$$

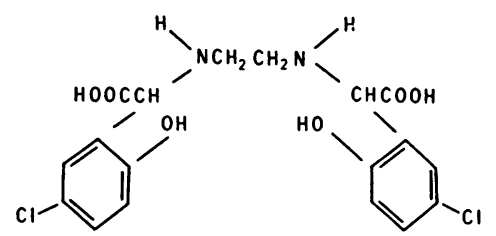

M

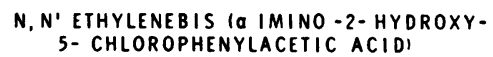

5- CHLOROPHENYLACETIC ACIDI

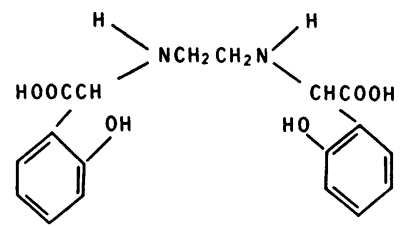

$\mathbf{N}$

N, N' ETHYLENEBIS [2-10-HYDROXYPHENYLI

$$
\text { GLYCINE] }
$$

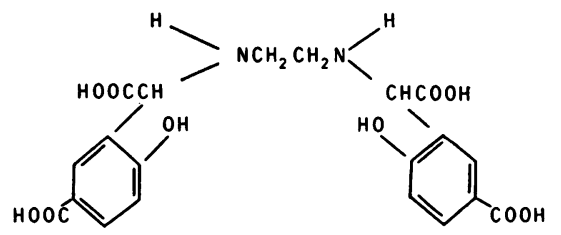

o

N, N' ETHYLENEBIS Ia IMINO -2- HYDROXY-

5- CARBOXYPHENYLACETIC ACIDI

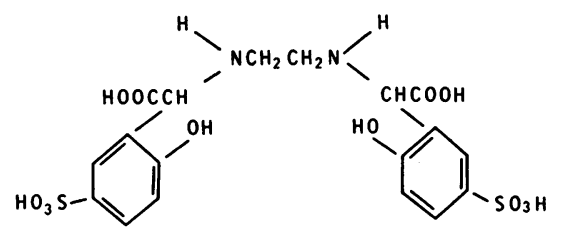

$$
\begin{aligned}
& \text { N, N' ETHYLENEBIS Ia IMINO -2- HYDROXY- } \\
& \text { 5- SULFOPHENYLACETIC ACIDI }
\end{aligned}
$$

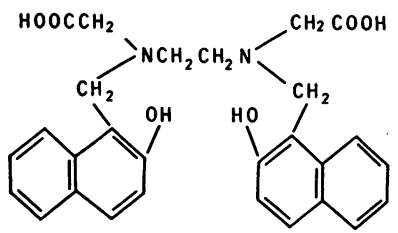

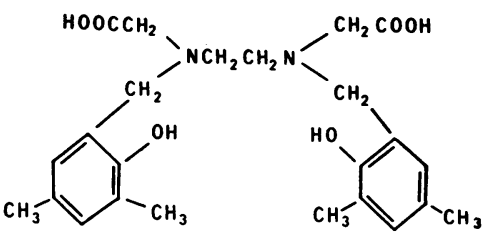

R

ETHYLENEDIAMINE - N, N' BISI2-HYDROXY3,5-DIMETHYLBENZYLI- DIACETIC ACID

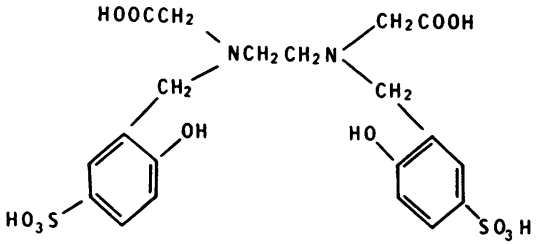

S

ETHYLENEDIAMINE-N, N' BIS 12- HYDROXY-5-SULFOBENZYLI- DIACETIC ACID

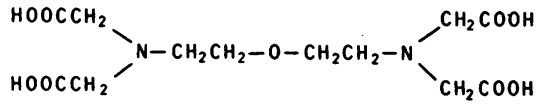

2, 2'- BIS [OI (CARBOXYMETHYL) AMINO]

T DIETHYL ETHER

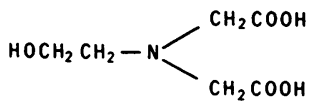

N-B- HYDROXYETHYLIMINODIACETIC $A C I D$

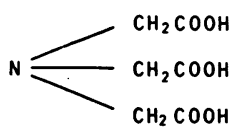

V

NITRILOTRIACETIC ACID INTA)

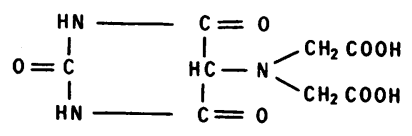

AMINOBARBITURIC ACID-N, N'DIACETIC ACID

a ETHYLENEDIAMINE-N, N'BISI2-HYDROXY-

Fig. 2. Structures of Ligands of Table II. The letters preceding the chemical names refer to the compounds listed in Table II. 
TABLE II

Chelate iron uptake*

\begin{tabular}{|c|c|c|c|c|c|}
\hline Chelate & $\log K_{M A}$ & $\begin{array}{l}\text { Ligand:iron } \\
\text { ratios }\end{array}$ & $\begin{array}{c}\text { Total } \\
\text { uptake }\end{array}$ & Hemolysate & Stroma \\
\hline $\begin{array}{l}\text { L. N,N'-Ethylenebis ( } \alpha \text { imino- } \\
\text { 2-hydroxy-5-methyl- } \\
\text { phenylacetic acid) }\end{array}$ & & $\begin{array}{r}2: 1 \\
5: 1 \\
10: 1\end{array}$ & $\begin{array}{l}1.7 \\
1.6 \\
1.5\end{array}$ & $\begin{array}{l}1.4 \\
1.4 \\
1.2\end{array}$ & $\begin{array}{l}0.3 \\
0.2 \\
0.3\end{array}$ \\
\hline $\begin{array}{c}\text { M. N,N'-Ethylenebis ( } \alpha \text { imino- } \\
\text { 2-hydroxy-5-chloro- } \\
\text { phenylacetic acid) }\end{array}$ & & $\begin{array}{r}2: 1 \\
5: 1 \\
10: 1\end{array}$ & $\begin{array}{l}5.6 \\
4.5 \\
3.9\end{array}$ & $\begin{array}{l}3.3 \\
3.1 \\
3.3\end{array}$ & $\begin{array}{l}2.3 \\
1.4 \\
0.6\end{array}$ \\
\hline $\begin{array}{l}\text { N. N,N'-Ethylenebis [2- } \\
\text { (o-hydroxyphenyl) } \\
\text { glycine] [EDDHA) }\end{array}$ & $\begin{array}{l}\text { Greater } \\
\text { than } \\
30\end{array}$ & $\begin{array}{r}2: 1 \\
5: 1 \\
10: 1\end{array}$ & $\begin{array}{l}0.7 \\
0.7 \\
0.6\end{array}$ & $\begin{array}{l}0.35 \\
0.4 \\
0.3\end{array}$ & $\begin{array}{l}0.35 \\
0.3 \\
0.3\end{array}$ \\
\hline $\begin{array}{l}\text { O. } \mathrm{N}, \mathrm{N}^{\prime} \text {-Ethylenebis ( } \alpha \text { imino- } \\
\text { 2-hydroxy-5-carboxy- } \\
\text { phenylacetic acid) }\end{array}$ & & $\begin{array}{r}2: 1 \\
5: 1 \\
10: 1\end{array}$ & $\begin{array}{l}0.5 \\
0.4 \\
0.4\end{array}$ & $\begin{array}{l}0.4 \\
0.3 \\
0.3\end{array}$ & $\begin{array}{l}0.1 \\
0.1 \\
0.1\end{array}$ \\
\hline $\begin{array}{l}\text { P. N,N'-Ethylenebis ( } \alpha \text { imino- } \\
\text { 2-hydroxy-5-sulfophenyl- } \\
\text { acetic acid) }\end{array}$ & & $\begin{array}{r}2: 1 \\
5: 1 \\
10: 1\end{array}$ & $\begin{array}{l}3.2 \\
1.2 \\
0.3\end{array}$ & $\begin{array}{l}2.2 \\
0.9 \\
0.2\end{array}$ & $\begin{array}{l}1.0 \\
0.3 \\
0.1\end{array}$ \\
\hline $\begin{array}{c}\text { Q. Ethylenediamine- } N, N^{\prime} \text { bis } \\
\text { ( } 2 \text {-hydroxy-1-naphtho- } \\
\text { benzyl)-diacetic acid }\end{array}$ & & $\begin{array}{r}2: 1 \\
5: 1 \\
10: 1\end{array}$ & $\begin{array}{l}7.2 \\
5.3 \\
5.6\end{array}$ & $\begin{array}{l}5.0 \\
4.2 \\
4.4\end{array}$ & $\begin{array}{l}2.2 \\
1.1 \\
1.2\end{array}$ \\
\hline $\begin{array}{l}\text { R. Ethylenediamine-N, } N^{\prime} \text { bis- } \\
\text { ( } 2 \text {-hydroxy-3,5-dimethyl } \\
\text { benzyl)-diacetic acid }\end{array}$ & & $\begin{array}{r}2: 1 \\
5: 1 \\
10: 1\end{array}$ & $\begin{array}{l}2.1 \\
2.1 \\
2.3\end{array}$ & $\begin{array}{l}1.7 \\
1.7 \\
1.9\end{array}$ & $\begin{array}{l}0.4 \\
0.4 \\
0.4\end{array}$ \\
\hline $\begin{array}{l}\text { S. Ethylenediamine-N, } N^{\prime} \text { bis } \\
\text { (2-hydroxy-5-sulfobenzyl)- } \\
\text { diacetic acid }\end{array}$ & & $\begin{array}{r}2: 1 \\
5: 1 \\
10: 1\end{array}$ & $\begin{array}{l}9.7 \\
2.2 \\
0.4\end{array}$ & $\begin{array}{l}6.4 \\
1.5 \\
0.3\end{array}$ & $\begin{array}{l}3.3 \\
0.7 \\
0.1\end{array}$ \\
\hline $\begin{array}{c}\text { T. } 2,2^{\prime} \text { Bis }[\text { di (carboxymethyl) } \\
\text { amino] diethyl ether }\end{array}$ & & $\begin{array}{r}2: 1 \\
5: 1 \\
10: 1\end{array}$ & $\begin{array}{l}0.2 \\
0.4 \\
0.4\end{array}$ & $\begin{array}{l}0.1 \\
0.3 \\
0.3\end{array}$ & $\begin{array}{l}0.1 \\
0.1 \\
0.1\end{array}$ \\
\hline $\begin{array}{l}\text { U. 2-Hydroxyethyliminodi- } \\
\text { acetic acid }\end{array}$ & & $\begin{array}{r}2: 1 \\
5: 1 \\
10: 1\end{array}$ & $\begin{array}{l}5.3 \\
5.0 \\
5.2\end{array}$ & $\begin{array}{l}3.2 \\
3.3 \\
3.2\end{array}$ & $\begin{array}{l}2.1 \\
1.7 \\
2.0\end{array}$ \\
\hline V. Nitrilotriacetic acid & 24.3 & $\begin{array}{r}2: 1 \\
5: 1 \\
10: 1\end{array}$ & $\begin{array}{l}9.6 \\
7.3 \\
6.4\end{array}$ & $\begin{array}{l}5.9 \\
5.4 \\
4.9\end{array}$ & $\begin{array}{l}3.7 \\
1.9 \\
1.5\end{array}$ \\
\hline $\begin{array}{l}\text { W. Aminobarbituric acid-N, } N^{\prime}- \\
\text { diacetic acid }\end{array}$ & & $\begin{array}{r}2: 1 \\
5: 1 \\
10: 1\end{array}$ & $\begin{array}{l}2.6 \\
1.1 \\
0.6\end{array}$ & $\begin{array}{l}1.0 \\
0.5 \\
0.3\end{array}$ & $\begin{array}{l}1.6 \\
0.6 \\
0.3\end{array}$ \\
\hline
\end{tabular}

* Calculated as micrograms of iron per milliliter of rabbit reticulocytes.

Log $K_{\text {MA }}$ values for Fe(III) chelates in Tables I and II obtained from (7).

and a second strip was cut into small segments and the radioactivity determined in the well counter. An estimate of the minimal radioiron incorporation into hemoglobin was established by division of the net counts for the hemoglobin fraction divided by the net counts for the hemolysate fraction.

\section{Results}

Iron-binding protein, iron transfer to reticulocytes. The range of total iron uptake per milliliter of reticulocytes in these experiments was 1.1 to 5.2 $\mu \mathrm{g}$ with a mean value of $2.8 \mu \mathrm{g}$. The amount present in the hemolysate fraction averaged $61 \%$ of the total uptake. The fraction was independent of the total quantity of iron taken up by the reticulocyte.

Iron transfer to mature erythrocytes. Like Jandl, Inman, and Simmons (9), we were unable to demonstrate iron uptake when the red cell suspension contained less than $0.5 \%$ reticulocytes.

A study of the transfer of iron from the compounds listed in Tables I and II to erythrocytes in a cell suspension of mature cells gave no evidence of measureable movement of iron to either cell stroma or hemolysate at equimolar or higher ligand/iron ratio. Compound $\mathrm{P}$ (Table II) was an apparent exception in this group. This sulfonic acid derivative yielded $2.0 \mu \mathrm{g}$ per $\mathrm{ml}$ of cells 
of iron to the mature cells ( $1.2 \mu \mathrm{g}$ on stroma, 0.8 $\mu \mathrm{g}$ in hemolysate) at a ligand/iron ratio of $2 / 1$ but did not provide any iron at higher ligand/iron ratios.

As a control study, we examined the uptake of iron chloride in a saline suspension of cells. Results of many such experiments were in full accord with published information in that at a total iron level of $4.2 \mu \mathrm{g}$ per $\mathrm{ml}$ of cells no less than $70 \%$ of the total iron uptake was deposited on the stroma $(5,9)$, from mature or immature cell suspensions.

Iron chelates, iron transfer to reticulocytes. Table I presents the data for the transfer of iron from a group of hydrophilic, aliphatic, and related chelates to a reticulocyte-rich red cell suspension. The values reported have been calculated per milliliter of reticulocytes on the basis of the reticulocyte population of the preparation studied. Iron is not transferred to reticulocytes in appreciable quantity from most of the compounds in this group at any ratio of ligand to metal. For some compounds ( $\mathrm{C}, \mathrm{E}, \mathrm{F}, \mathrm{I}, \mathrm{J}$, and $\mathrm{K}$ ) at low ligand/ metal ratios, some iron transfer to the reticulocyte does occur. Unlike IBP, most of the iron in these cases is adherent to the stroma of the cell. With all these compounds an increase in ligand ratio results in a decrease in total iron uptake by the cells, especially the stromal fraction.

The transfer of iron to reticulocytes by the compounds listed in Table II is similar in pattern to that of IBP. Inspection of the uptake values at $10: 1$ ratio, where the chelated iron species is most pronounced, shows that the distribution of the reticulocyte iron is usually predominantly in the hemolysate. Compounds $\mathrm{L}$ through $\mathrm{P}$ represent a series in which the iron-binding portion of the molecule is constant, but systematic substitution on the aryl ring provides variability in the polar nature of the iron chelate. The unsubstituted compound, $\mathrm{N}$, is intermediate in its iron delivery capability between the more lipotropic methyl and chlorine substituted congeners $\mathrm{L}$ and $\mathrm{M}$ and the more hydrophilic carboxyl and sulfonic acid derivatives $\mathrm{O}$ and $\mathrm{P}$.

A second structural sequence (compounds $Q$, $R$, and $S$ ) shows an analogous pattern of relation between molecular structure and iron delivery. Again, the more hydrophobic compounds, $Q$ and
$\mathrm{R}$, at the 10:1 molar ratio, bearing the bulky hydrocarbon naphthyl and the dimethylbenzylhydroxy structures, provide optimal iron transfer to the reticulocyte with a high proportion of metabolically useful iron in a cell hemolysate. The amount of iron transported by the more hydrophilic sulfonic acid derivative, compound $S$, is lower but again with good distribution between stromal and hemolysate iron fractions.

The series of compounds $\mathrm{T}$ through $\mathrm{V}$ may be considered as derivatives of iminodiacetic acid in which the remaining hydrogen of the amino group has been substituted by a variably complex grouping such as the beta ethyl ether, compound $T$, the beta hydroxyethyl substituent of compound $U$, the more polar acetic acid, compound V, and the bulky barbituric acid group of compound W. All the compounds in this series provide iron to the reticulocyte with a hemolysate/stromal ratio similar to that of iron-binding protein.

Radioiron incorporation into hemoglobin. Hemoglobin precipitation showed that a minimum of $10 \%$ of the hemolysate fraction from ferric chloride, $40 \%$ of the hemolysate fraction from IBP, and $80 \%$ of the hemolysate from compound $\mathrm{V}$ was incorporated into hemoglobin. Qualitative data for compounds $\mathrm{L}, \mathrm{M}$, and $\mathrm{N}$ demonstrated radioactivity incorporation in hemoglobin. These results were confirmed by the electrophoretic studies, which showed the localization of radioactivity concomitant with the hemoglobin.

\section{Discussion}

The circulating iron of the plasma is rapidly removed, almost entirely by the marrow, in conditions of high iron utilization (10-12). Most evidence suggests that the mechanism of this plasma iron removal involves the transfer of transferrin iron to immature red cells $(5,9,13$, 14). The chemical mechanisms by which transferrin is able to achieve this selective result are presently unknown.

The formation of the soluble but poorly dissociated iron transferrin chelate may provide a buffer system to maintain a continuous reservoir for low levels of ionic iron in the plasma. Such a function for transferrin would inhibit the characteristic nonselective adsorption of inorganic iron at metabolically inert sites on the reticulo- 
cyte stroma. In addition to such a solubility controlling function for iron in plasma, the selective structural characteristics of the iron transferrin chelate may permit delivery of the metal to sites on the reticulocyte membrane that permit rapid metabolic utilization of the deposited metal. Synthetic chelating agents provide a useful and precise tool to examine these possible functions for the naturally occurring iron-chelating agent, transferrin.

Choice of a suitable sequence of iron-binding agents makes it possible to "set" the ionic concentration of the free metal ion species at predetermined levels below, equal to, or above that characteristic of the interaction of transferrin and ferric ion. A convenient measure of this value is the $\log K_{\mathbf{M A}}$ (15). For transferrin and ferric ion, $\log \mathrm{K}_{\mathbf{M A}}$ has been variously reported as approximately 27 (16), 27.7 for the first iron atom of transferrin, and 29 or 30.2 for the second iron atom of the molecule $(17,18)$. Were the metabolic function of transferrin related simply to its ability to maintain a soluble buffer system for the iron ion at a given low concentration, one would expect that the compounds in Tables I and II would show a regular relation between iron-binding ability as measured by $\log \mathrm{K}_{\mathbf{M A}}$ and the uptake of iron by the hemolysate fraction of the reticulocyte. This is not the case. Compounds $\mathrm{V}$ and $\mathrm{N}\left(\log \mathrm{K}_{\mathrm{MA}} 24.3\right.$ and greater than 30 , respectively) $(19,20)$, at the ends of the iron-binding spectrum vis-à-vis transferrin, are both able to provide the reticulocyte with metabolically useful iron as determined by incorporation into the heme molecule.

The data in Tables I and II suggest, however, that a relation does exist between the ionic iron concentration and the degree of nonspecific adsorption on the reticulocyte membrane. As the ratio of chelating agent to ferric ion is increased from $2: 1$ to $10: 1$, the degree of stromal iron deposition decreases, for example, with compounds $I, J$, and $K$, and $M, P$, and $S$. Since the result of increase in chelating agent concentration in these systems is to decrease the free metal ion concentration (7), one may presume that the change in ionic iron concentration, so induced, is at the critical level for nonspecific iron adsorption to the reticulocyte stroma.
Our present studies also provide some information on the structural aspects of iron binding that permit delivery of the metal to the young erythrocyte. The compounds utilized are divisible into two broad groups based on their ability to function in vitro in a manner analogous to the specific iron-binding protein of plasma. In the highest chelate iron molar ratios, at which the metal may be presumed maximally in the form of the iron chelate, the compounds in Table I inhibit the nonspecific adsorption of iron on the reticulocyte membrane by depression of the ionic iron in the medium. The iron chelate so formed, however, is unable to deposit the metal on those sites on the membrane from which it may be further utilized for metabolic conversion to iron porphyrin in the intracellular compartment. The most characteristic structural aspect of the hydrophilic iron chelates of the compounds in Table I is the net negative charge of the molecule at neutral $\mathrm{pH}$. In this respect these iron chelates are similar to the red cell. It has been suggested that acid groups on the red cell membrane impart a negative charge to the surface of the cell; this negative charge may be the basis of the intercellular repelling force that prevents the red cells from touching each other (21). In our study, the nonspecifically adsorbable positively charged ferric ion is converted to a negatively charged iron chelate that is also repelled from the cell surface. The net result, as observed, is decreased iron adsorption, specific and nonspecific, from iron chelates of this structural type. Similar results had been earlier reported by Jandl and co-workers (5) for EDTA (compound A, Table I).

Many of the synthetic iron chelates in Table II are able to fully mimic the function of the ironbinding protein in delivery of iron to the reticulocyte for conversion to hemoglobin. The sequence of compounds $\mathrm{L}$ to $\mathrm{P}$ is especially illuminating in this respect. Compounds $\mathrm{L}, \mathrm{M}$, and $\mathrm{N}$ provide a lipophilic iron chelate. The methyl and chloro substituents on the aryl ring enhance this molecular characteristic. As one proceeds from the unsubstituted structure of compound $\mathrm{N}$ to the negatively charged carbaxylate and sulfonate acid aryl substituents (compounds $\mathrm{O}$ and $\mathrm{P}$ ), the molecular envelope for the iron shifts in charac- 
ter to a definite negatively charged surface. One may note the corresponding decrease in transfer of the iron to the reticulocyte. Our results agree, concerning reticulocyte uptake and hemoglobin incorporation, with those reported for compound $\mathrm{N}$ (Table II) by Cleton, Turnbull, and Finch (22), who demonstrated that 50 to $90 \%$ of the radioiron uptake was incorporated into hemoglobin. Other compounds in Table II that function satisfactorily for iron transport are also characterized by a neutral lipotropic molecular structure.

The mechanisms by which iron presented to the reticulocyte in the form of a suitable small molecular chelate gains access to the intracellular compartment and becomes available for hemoglobin incorporation have not been established. To date our studies indicate that the route of iron absorption from some of the iron chelates differs from that for iron transferrin, since the processes are neither competitive nor respond in the same way to challenge by metabolic inhibitors (23). Our work does not preclude the possibility that the iron chelate moiety enters the cell as such.

We have interpreted the results of these studies of the transfer of iron from synthetic chelating agents to the reticulocyte to support a dual concept of the metabolic function of iron-binding protein in plasma. In this view, transferrin serves as a soluble reservoir of ferric ion in the vascular system, which maintains the free metal ion concentration at a level low enough to minimize nonselective adsorption on the reticulocyte membrane. Interaction of iron with other plasma constituents is simultaneously inhibited.

A second major effect of protein iron binding is to so change the charge and environment of the metal ion that it may approach areas on the reticulocyte membrane surface where active metabolic intervention may then further the processes of iron utilization. Whether the subsequent reaction sequence involves reductive processes as has been postulated for certain tissue iron storage areas (24), the intervention of metabolically controlled small molecular carriers as has been alternatively postulated (25-27), or other active transport mechanisms for movement of iron transferrin to the reticulocyte (5), awaits clarification.

\section{Summary}

The transfer of iron from synthetic iron chelates of varied structure to rabbit reticulocytes has been studied. Iron-binding compounds of suitable structure such as $\mathrm{N}, \mathrm{N}^{\prime}$-ethylenebis ( $\alpha$ imino-2-hydroxy-5-methylphenylacetic acid) and $\mathrm{N}, \mathrm{N}^{\prime}$-ethylenebis ( $\alpha$ imino-2-hydroxy-5-chlorophenylacetic acid ( $L$ and $M$ ) simulate the functions of transferrin in inhibiting nonselective membrane adsorption of iron and promoting utilization of the iron for incorporation into hemoglobin. Highly polar anionic iron chelates such as those of diethylenetriaminepentaacetic acid and ethylenediaminetetraacetic acid inhibit both nonselective deposition of iron on reticulocyte membrane and utilization of the metal for hemoglobin biosynthesis.

Our studies with synthetic model compounds clarify the dual role of transferrin in regulating ionic iron levels in plasma to minimize nonselective membrane adsorption and shed light on the protein's structural characteristics that promote selective iron delivery to the reticulocyte for hemoglobin synthesis.

\section{Acknowledgment}

The authors thank the Geigy Chemical Company, Ardsley, N. Y. for assistance in this investigation.

\section{References}

1. Laurell, C. B. Studies on the transportation and metabolism in the body with special reference to the iron binding component in human plasma. Acta physiol scand. 1947, 14 (suppl. 46), 1.

2. Bothwell, T. H., and C. A. Finch. Iron Metabolism. Boston, Little, Brown, 1963, p. 141.

3. Warner, R. C. The metal chelate compounds of proteins. Trans. N. Y. Acad. Sci. 1954, 16, 182.

4. Warner, R. C., and I. Weber. The metal combining properties of conalbumin. J. Amer. chem. Soc. 1953, 75, 5094.

5. Jandl, J. H., J. K. Inman, R. L. Simmons, and D. W. Allen. Transfer of iron from serum iron-binding protein to human reticulocytes. J. clin. Invest. 1959, 38, 161.

6. Brecher, G. New methylene blue as a reticulocyte stain. Amer. J. clin. Path. 1949, 19, 895.

7. Chaberek, S., and A. E. Martell. Organic Sequestering Agents. New York, John Wiley and Sons, 1959.

8. Kruh, J., and H. Borsook. Hemoglobin synthesis in rabbit reticulocytes in vitro. J. biol. Chem. 1956, 220, 905. 
9. Jandl, J. H., J. D. Inman, and R. L. Simmons. Transfer of iron and cobalt from serum ironbinding protein to human reticulocytes. Clin. Res. Proc. 1957, 5, 144.

10. Wasserman, L. R., I. A. Rashkoff, D. Leavitt, J. Mayer, and S. Port. The rate of removal of radioactive iron from the plasma-an index of erythropoiesis. J. clin. Invest. 1952, 31, 32.

11. Bothwell, T. H., A. V. Hurtado, D. M. Donohue, and C. A. Finch. Erythrokinetics: IV. The plasma iron turnover as a measure of erythropoiesis. Blood 1957, 12, 409.

12. Pollycove, M., and R. Mortimer. The quantitative determination of iron kinetics and hemoglobin synthesis in human subjects. J. clin. Invest. 1961, 40, 753.

13. Walsh, R. J., E. D. Thomas, S. K. Chow, R. G. Fluharty, and C. A. Finch. Iron metabolism: heme synthesis in vitro by immature erythrocytes. Science 1949, 110, 396.

14. Paoletti, C. Role des $\beta$-globulinis plasmatiques dans le' transport du fer utilise' par les cellules erythroformatrices. C. R. Acad. Sci. (Paris) 1957, 245, 377.

15. Rubin, M., and J. V. Princiotto. Chelation as a basic biological mechanism. J. agricultural and food Chem. 1963, 11, 98.

16. Rubin, M., J. Houlihan, and J. V. Princiotto. Chelation and iron metabolism. I. Relative iron binding of chelating agents and siderophilin in serum. Proc. Soc. exp. Biol. (N. Y.) 1960, 103, 663.

17. Davies, B., P. Saltman, and S. Benson. The sta- bility constants of the iron-transferrin complex. Biochem. biophys. Res. Commun. 1962, 8, 56.

18. Korman, S. Iron metabolism in man. Ann. N. Y. Acad. Sci. 1960, 88, 460.

19. G. Schwarzenback, and J. Heller. Complexons XXI. The iron complexes of nitrilotriacetic acid. Helv. chim. Acta 1951, 34, 1889.

20. Frost, A. E., H. Freedman, S. Westerback, and A. E. Martell. Chelating tendencies of $\mathrm{N}, \mathrm{N}^{\prime}$ ethylene bis [2-(o-hydroxy phenyl) glycine]. J. Amer. chem. Soc. 1958, 80, 530.

21. Harris, J. W. The Red Cell. Cambridge, Harvard University Press, 1963, p. 199.

22. Cleton, F., A. Turnbull, and C. A. Finch. Synthetic chelating agents in iron metabolism. J. clin. Invest. $1963,42,327$.

23. Aserkoff, B., E. J. Zapolski, M. Rubin, and J. V. Princiotto. The transfer of iron to rabbit reticulocytes by serum iron-binding protein and a synthetic iron-binding chelate. Fed. Proc. 1963, 22, 665.

24. Mazur, A., S. Green, and A. Carleton. Mechanisms of plasma iron incorporation into hepatic ferritin. J. biol. Chem. 1960, 235, 595.

25. Bass, R., and P. Saltman. Accumulation of iron by rat liver cell suspensions. Exp. Cell Res. 1959, 16, 182.

26. Brown, E. B., and M. L. Rather. Studies of the mechanism of iron absorption. I. Iron uptake by the normal rat. J. Lab. clin. Med. 1963, 62, 357.

27. Charley, P. J., C. Stitt, E. Shore, and P. Saltman. Studies in the regulation of intestinal absorption. J. Lab. clin. Med. 1963, 61, 397. 